\title{
THE INTERTEXTUAL RELATIONSHIP OF DANIEL 12:2 AND ISAIAH 26:19: \\ EVIDENCE FROM QUMRAN AND THE GREEK VERSIONS
}

\author{
Daniel P. Bailey
}

The language of 'awakening' from the sleep of death in Daniel 12:2 is apparently borrowed directly from Isaiah 26:19: 'Awake (הִִָיצו) and shout for joy, you dwellers in the dust!' (MT). But while this echo has been recognised by scholars both ancient (Jerome) ${ }^{1}$ and modern, ${ }^{2}$ there remains a question about the underlying text. As $\mathrm{M}$. Hengel has rightly noted, the verbal parallel is closer if we assume that the text of Isaiah 26:19 read by the author of Daniel contained

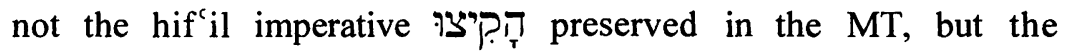
imperfect קיצ' attested in 1QIsa ${ }^{a}{ }^{3}$ The verb forms in Daniel and Isaiah are then identical:

Daniel 12:2

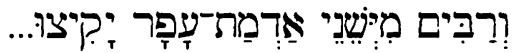

Many of those who sleep in the dust of the earth will awake...

\section{Isaiah 26:10}

\section{QIsaa: עיקיצו וירננו שוכני עפר}

The dwellers in the dust will awake and shout for joy.

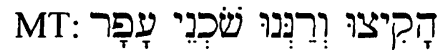

Awake and shout for joy, you dwellers in the dust!

While it is tempting to ask whether the texts of Daniel and Isaiah could have influenced one other in Qumran, my question here concerns another part of the textual tradition-the currency of the

1 Cf. J.F.A. Sawyer, The Fifth Gospel: Isaiah in the History of Christianity (Cambridge: CUP, 1996), pp. 186-87.

2 E.g. J.J. Collins, Daniel (Hermeneia; Minneapolis: Fortress, 1993), p. 392.

3 M. Hengel, 'Zur Wirkungsgeschichte von Jes 53 in vorchristlicher Zeit', in Der leidende Gottesknecht: Jesaja 53 und seine Wirkungsgeschichte, ed. B. Janowski and P. Stuhlmacher (FAT 14; Tübingen: Mohr Siebeck, 1996), p. 60.

4 Text in M. Burrows, ed., The Dead Sea Scrolls of St. Mark's Monastery, vol. 1: The Isaiah Manuscript and the Habakkuk Commentary (New Haven: American Schools of Oriental Research, 1950), plate 21. 
Qumran text of Isaiah 26:19 among the Vorlagen of the Greek versions. Hengel believes that the Septuagint translator together with his later revisers used a Vorlage that included the imperfect יקיצ', as in 1QIsaa. ${ }^{5}$ This is suggested by the future tenses of the verbs $\dot{\varepsilon} \gamma \varepsilon \rho \theta \dot{\eta} \sigma o v \tau \alpha l$ in the LXX and $\dot{\varepsilon} \xi v \pi v \imath \sigma \theta \dot{\eta} \sigma o v \tau \alpha l$ in the minor versions. These Greek verbs line up with the MT's הָָ according to F. Field, or with יקיצ' according to Hengel.

However, there may well be an error in Field's Greek-Hebrew alignment. Hengel's claim would then need modification. Field's summary of the evidence in Isaiah 26:19 runs:

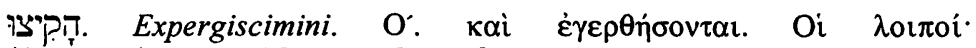
$\dot{\varepsilon} \xi \cup \pi v i \sigma \theta \dot{n} \sigma 0 v \tau \alpha 1$. (Origenis Hexaplorum, 2:475)

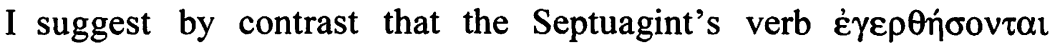
should be aligned opposite the preceding verb קוּמוּן', as below:

\begin{tabular}{|c|c|c|c|}
\hline MT & Vulgate & LXX & MT translated \\
\hline 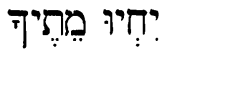 & vivent mortui tui & 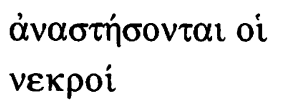 & $\begin{array}{l}\text { Your dead will } \\
\text { live, }\end{array}$ \\
\hline נְבְלָתִי :יקוּמוּן & $\begin{array}{l}\text { interfecti mei } \\
\text { resurgent }\end{array}$ & 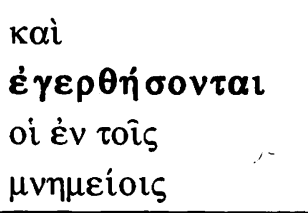 & $\begin{array}{l}\text { their (lit. } m y) \\
\text { corpses will } \\
\text { rise. }\end{array}$ \\
\hline דָקִיצוּוּ & expergiscimini & (Field's alignment) & Awake \\
\hline 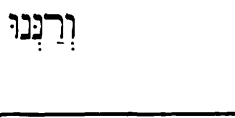 & $\begin{array}{l}\text { et laudate (Field } \\
\text { jubilate) }\end{array}$ & 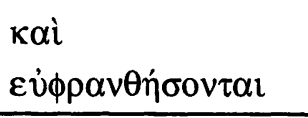 & $\begin{array}{l}\text { and shout for } \\
\text { joy, }\end{array}$ \\
\hline 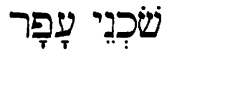 & $\begin{array}{l}\text { qui habitatis in } \\
\text { pulvere }\end{array}$ & oi દ̇v $\tau \hat{n} \gamma \hat{\eta}$ & $\begin{array}{l}\text { you dwellers in } \\
\text { the dust! }\end{array}$ \\
\hline
\end{tabular}

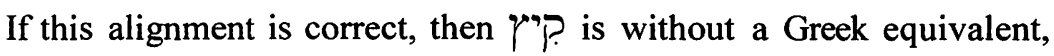
complicating Hengel's attempt to use the Greek versions to prove the popularity of the Qumran reading קיצו'.

5 Cf. Hengel, 'Zur Wirkungsgeschichte', p. 60: 'In Dan 12,2a stammt die Formulierung "viele der Schlafenden des Staublandes werden aufwachen"

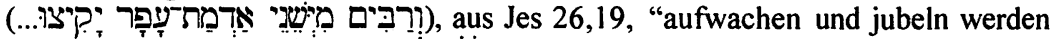

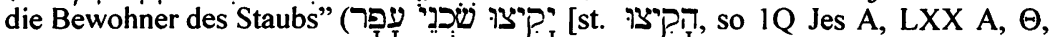
$\Sigma]$ )'. Here 'LXX A' is a misprint; read 'LXX, A[quila]'. 
My proposed alignment is suggested first by the structure of the Hebrew and Greek versions. Both have only three grammatical subjects in Isaiah 26:19a: 'your dead' = ๆ מִ = oi vekpoí; 'my

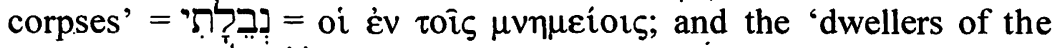

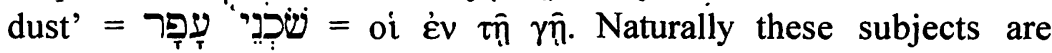
attached to verbs. There are four verbs in the Hebrew: חוּד (both qal impf.), קִיץ (hif. impv. MT, impf. 1QIsaa), and רִּנִ (pi el impv. MT, impf. 1QIsaa). The third of the three Hebrew subjects therefore has to take two verbs. In the Greek, however, the number of subjects and verbs matches, leaving one of the Hebrew verbs untranslated. Field implies that קils is the untranslated verb, while Hatch and Redpath (Concordance) imply that there is no untranslated verb: غ่ $\gamma \varepsilon \rho \theta \dot{\eta} \sigma o v \tau \alpha l$ supposedly reflects both stylistically it would be more natural for the first two Greek verbs to correspond to first two Hebrew verbs. The LXX translator apparently took up the first subject and its verb, the second subject and its verb, and then the third subject and its nearest verb, which is clearly

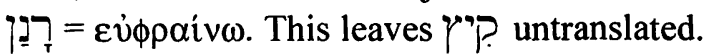

This alignment is also suggested by the Septuagint translator's treatment of Isaiah 26:14. 'The dead will not live; the departed spirits

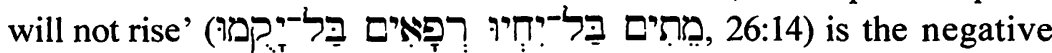
counterpart of 'Your dead will live, their corpses will rise' (26:19) - at least in the Hebrew, where the first two verbs each verse. In the LXX, however, these verbs are translated

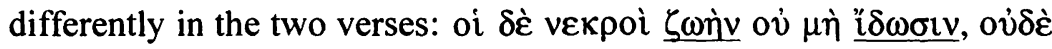

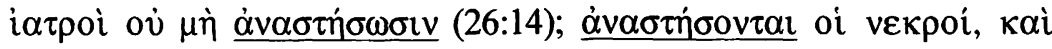

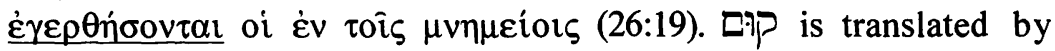

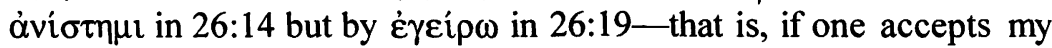
alignment over Field's. The sense of the Hebrew verb helps determine the alignment.

The verb קוק has the sense 'to rise from the dead' in Isaiah 26:14, 19 and at least three other OT passages: 2 Kings 13:21; Job 14:12; Psalm 88:11; usually the sense is negative, of the dead not being destined to rise (Is. 16:19 and $2 \mathrm{Ki}$. 13:21 are the exceptions). In all

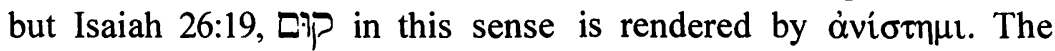

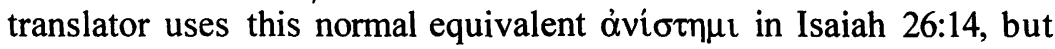
encounters a complication with רפאים. Instead of the MT pointing

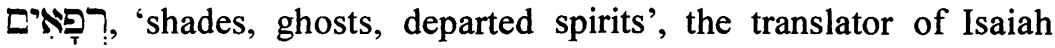
26:14 (as well as the translator of Ps. 88 [LXX 87]:11) has read רִפִִים, 'healers, physicians', and has translated it accordingly by i $\alpha \tau \rho o i$, as in 2 Chronicles 16:12 and Job 13:4. Yet the Greek still makes sense if 


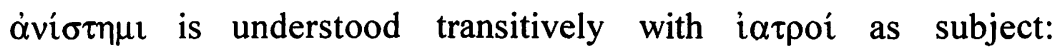
'physicians will not raise [sc. them]' (Is. 26:14).

A different translation procedure is used in Isaiah $26: 19$. Here, the translator uses áví $\tau \uparrow \mu \mathrm{t}$ intransitively (cf. $2 \mathrm{Ki} .13: 21$; Jb. 14:12), not for the second verb קוף as in 26:14 but for the first verb live'. This is a free and very unusual translation of only twice in the OT (Is. 26:19; 38:9), despite 282 OT occurrences of तָ the first verb in Isaiah 26:19 forces a new translation for the second

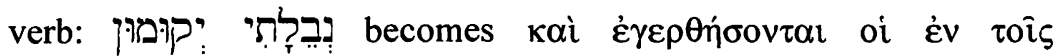
$\mu v \eta \mu \varepsilon i ́$ c s. The 'corpses' - or 'those in the graves' in the Greek (cf.

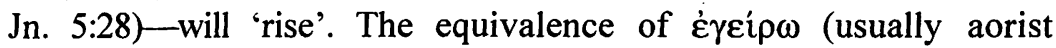
passive) and $\bar{D}$ in the weakened sense of 'rising' or setting out to take action is common enough in the LXX (1 Ch. 10:12; 22:19; $2 \mathrm{Ch}$. $21: 9 ; 22: 10$ ), but Isaiah $26: 19$ is the only place in the OT where both

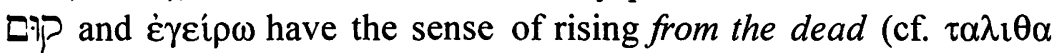

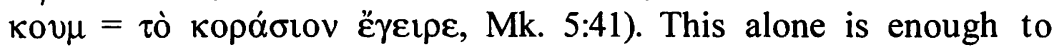
suggest their translational equivalence herè.

Field's alignment of $\dot{\varepsilon} \gamma \varepsilon i p \omega$ with $Y$ P in Isaiah 26:19 depends on the translation equivalents elsewhere in the LXX. In the aorist

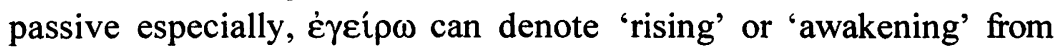
sleep, translating P. P. (Gn. 41:4, 7; Je. 28:39). The required sense of awakening from the sleep of death occurs in 2 Kings 4:31, where the

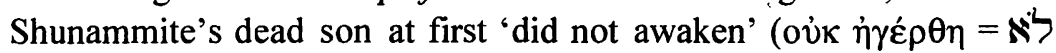
(T). But even when it clearly has this sense of 'rising' from sleep,

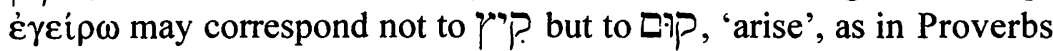
6:9 (future passive). There is therefore no necessary equivalence between $\dot{\varepsilon} \gamma \varepsilon i \rho \omega$ and $Y$ P. in Isaiah 26:19. Field is probably right to suggest that the reading of the minor versions, $\dot{\varepsilon} \xi v \pi v i \sigma \theta \eta \dot{\eta} \sigma o v \tau \alpha \mathrm{t}$, 'they shall awake from sleep' (cf. Job 14:12), was inspired by rather than by $\mathrm{D}$. But this only proves that the revisers glanced at קיץ once the three-verb structure of the LXX was already fixed; it does not determine the original LXX alignment.

Nevertheless, Hengel's thesis about the popularity of the Qumran text type is still tenable. The renderings of the fourth verb in Isaiah 26:19 are all future, suggesting an imperfect וירנגו

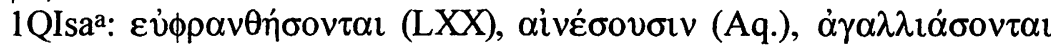
(Sym.), $\dot{\alpha} \lambda \alpha \lambda \alpha^{\prime} \xi_{0} v \sigma v v$ (Theod.). Since וירננו is stylistically inconceivable apart from a preceding imperfect יקיצו, the latter can probably be presupposed in the Vorlagen of all the Greek versions. The author of Daniel 12:2 was indeed reading a popular text. 